Review

\title{
Survivability of Salmonella and Escherichia coli O157:H7 Pathogens and Food Safety Concerns on Commercial Powder Milk Products
}

\author{
Roshan Paswan and Young W. Park * \\ Georgia Small Ruminant Research \& Extension Center, Fort Valley State University, \\ The University System of Georgia, Fort Valley, GA 31030, USA; roshan.paswan@fvsu.edu \\ * Correspondence: parky@fvsu.edu; Tel.: +1-478-827-3089
}

Received: 10 September 2020; Accepted: 19 October 2020; Published: 21 October 2020

check for updates

\begin{abstract}
Milk and dairy products are susceptible to the incidence of foodborne illnesses by numerous pathogens, including Listeria monocytogenes, Salmonella spp., Escherichia coli, enteropathogenic Campylobacter jejuni, Yersinia enterocolitica, Cronobacter (Enterobacter sakazakii) and Staphylococcus aureus. Annually Salmonella infections cause approximately 93.8 million cases of gastroenteritis and 155,000 deaths worldwide. Including meat and poultry, dairy products are the most commonly contaminated foods by Salmonella. Studies show that Salmonella, Escherichia coli O157:H7 and Listeria monocytogenes are among the top 5 pathogens causing hospitalization and life-threatening foodborne illnesses. The U.S. Centers for Disease Control and Prevention (CDC) estimated that annually around 1.2 million foodborne illnesses with more than 23,000 hospitalizations, 450 deaths and 130 outbreaks were attributed to Salmonella infection in the U.S. The Salmonella enteric in skim milk powder survived at three months storage, with water activity as low as 0.33 . With respect to Escherichia coli O157:H7, it is capable of causing disease at a low dosage, ranging from 5-50 cells. Viable cells of Escherichia coli O157:H7 reportedly survive in infant formula powder for one year at $5{ }^{\circ} \mathrm{C}$. The survivability of Escherichia coli in powder milk was significantly reduced with the synergistic effects of storage time and temperature. The U.S. Dairy Export Council recommends that milk powder should be stored in a cool and dry place, at a temperature not to exceed $27^{\circ} \mathrm{C}$, and a relative humidity not to exceed $65 \%$. Reports have recommended that milk powder products need to be stored in light, oxygen, and moisture-proof containers. In this article, the survival of the major foodborne pathogens including Salmonella and Escherichia coli O157:H7 in powdered milk products from common dairy species such as cow and goats are reviewed.
\end{abstract}

Keywords: Salmonella; Escherichia coli O157:H7; pathogens; survivability; powdered milk; foodborne illness; storage stability

\section{Introduction}

In a food safety perspective, dry foods, such as powdered milk, are often considered to be safe from microbial contamination, since harmful microorganisms cannot sustain or grow in dry foods due to low moisture content and water activity [1,2]. However, dehydrated foods can be contaminated posing as vehicles for foodborne pathogens [1,2].

It is well known that powder milk has the advantage of controlling the growth of pathogenic and spoilage microorganisms due to its low water activity $\left(\mathrm{a}_{\mathrm{w}}\right)$ and moisture content [1-3]. However, dry food often can pose a possible food safety risk because pathogens can survive in an environment of low moisture and water activity $\left(\mathrm{a}_{\mathrm{w}}\right)[3,4]$. In low $\mathrm{a}_{\mathrm{w}}$ foods, water is in glassy and rubbery states, so the water has limited mobility which helps water molecules contact bacterial cells during their interaction, and thereby bacterial cells normally survive longer periods in dried foods such as powdered milk [3]. 
Several foodborne pathogens have been identified in raw milk, and these organisms can also opportunistically enter the milk during processing and contaminate the microbiologically safe original milk and dairy products. Salmonella is one of the known pathogens in milk, and belongs to the family of Enterobacteriaceae, which are rod-shaped, Gram-negative, facultative anaerobic bacteria, and can use glucose for fermentation [5].

It has been estimated that annually 1.4 million illnesses account for Salmonella infection, with more than 16,000 hospitalizations and 580 deaths in the U.S. [6]. The U.S. Department of Agriculture (USDA), U.S. Public Health Service, and U.S. Food and Drug Administration (FDA) conducted an independent survey for Salmonella in dried milk, and the FDA reported that 3 to $5 \%$ of powder milk products tested were shown positive, and the USDA found $2 \%$ of 200 samples positive [5]. Large number of powder milk samples had been examined, and 11 serotypes of Salmonella had been isolated from the powder samples collected from more than 20 milk drying plants in 11 states in the United States [7].

Escherichia coli O157:H7 is another major foodborne pathogen in milk and its products causing serious illness. The bacterium Escherichia coli belongs to the family of Enterobacteriaceae [8,9], and these organisms are rod-shaped, Gram-negative, facultative anaerobic bacteria, and can use lactose and glucose for fermentation [9]. Escherichia coli O157:H7 is capable of causing a variety of diseases in humans, ranging from mild cases of diarrhea to extreme cases of hemorrhagic colitis and hemolytic uremic syndrome [10]. Viable cells of Escherichia coli O157:H7 are capable of surviving in infant formula powder for as long as one year at a storage temperature of $5{ }^{\circ} \mathrm{C}$ [11]. Escherichia coli O157:H7 shows a high level of virulence, with the capability of causing disease at a low dosage, ranging from 5-50 cells [12].

Powder milk is an important source of food ingredient used for various food products such as bakery products, ice cream, chocolate, yogurt, infant formula, cheeses and reconstituted milk [13]. The advantages of powder milk are the extension of shelf life of milk and easier to transport by reducing volume [14,15]. Due to lipid oxidation and the Maillard reaction, dehydrated milk has certain problems such as physical changes, caking and cohesion that occurs during storage; which can deteriorate effects on sensory properties of powder milk products [15].

Pathogens can enter into food chains from milking at farms, dairy processing facilities, drying dairy plants, storage and distribution, and can survive in the processed products. The contaminated pathogens in the products can cause serious foodborne outbreaks or illness of the consumers. The objective of this paper is to review the survivability of the major foodborne pathogens such as Salmonella and Escherichia coli O157:H7 in powdered milk products, as well as to evaluate the storage stability of dehydrated milk products in relation to food safety.

\section{Pathogenic Microorganisms in Milk and Dairy Products}

Milk from the mammary gland has nearly neutral $\mathrm{pH}$ that is a suitable medium for growth and survival of many pathogenic and opportunistic microorganisms. Owing to modern and standardized milk and dairy products production practices, potential threats of pathogenic bacterial outbreaks have steadily declined [16]. However, a number of outbreaks of milk-borne diseases have caused serious concerns about milk-borne pathogens $[16,17]$. Quite a few pathogens are involved in spoilage of milk and dairy products, and these microbes include psychotropic Gram-negative bacteria, coliform bacteria, and yeast and mold [4-18].

Reports have shown that milk and dairy products are susceptible to foodborne diseases by numerous pathogens, including Listeria monocytogenes, Campylobacter jejuni, Salmonella spp., Yersinia enterocolitica, Staphylococcus aureus, Cronobacter (Enterobacter sakazakii) and enteropathogenic Escherichia coli $[19,20]$. Various factors are responsible for the prevalence and incidence of pathogens in milk and its products, such as farm size, the number of animals on the farm, milking hygiene, farm management practices, sanitary condition of processing environment, post-processing, transportation, geographical location, and season [4-17]. 


\section{Survival of Major Pathogens in Dehydrated Milk Products}

Studies have revealed that Salmonella spp., Escherichia coli O157:H7, Listeria monocytogenes, Campylobacter jejuni, and Clostridium botulinum are the top 5 pathogens that cause hospitalization and as well as life-threatening foodborne illnesses present in dehydrated milk products [21].

\subsection{Survival of Salmonella in Dried Milk Products}

Moisture content of the milk powder has a significant influence on the heat resistance of Salmonella. In a study on the heat resistance of Salmonella and the effect of storage on survival in non-fat dried milk, McDonough et al., 1968 [5] observed that a cocktail of Salmonella (Salmonella senftenberg 775W, Salmonella Typhimurium TM1, and Salmonella new Brunswick 1608) in non-fat dry milk powder (4\% moisture) were extremely resistant to dry heat destruction. The researchers observed that neither $60{ }^{\circ} \mathrm{C}$ nor $76.6^{\circ} \mathrm{C}$ eliminated Salmonella cells after $10 \mathrm{~h}$ by dry heat (Table 1). Moreover, the $2 \mathrm{~h}$ dry heat at $85^{\circ} \mathrm{C}$ or $45 \mathrm{~min}$ dry heat at $115.5^{\circ} \mathrm{C}$ were not enough to destroy salmonella in $4 \%$ moisture powder milk product (Table 1). However, applying a high temperature $\left(115.5^{\circ} \mathrm{C}\right.$ for $\left.1 \mathrm{~h}\right)$ for $4 \%$ moisture product was too intense to destroy Salmonella, and resulted in imparted yellow, burned appearance to the milk powder [5].

Table 1. Survival of Salmonella in non-fat dried milk (4\% moisture) subjected to dry heat (adapted from [5]).

\begin{tabular}{ccccc}
\hline \multirow{2}{*}{ Exposure Time } & \multicolumn{4}{c}{ Survival Salmonella Count (CFU) at Temp ${ }^{\circ} \mathbf{C}$} \\
\cline { 2 - 5 } & $\mathbf{6 0}$ & $\mathbf{7 6 . 6}$ & $\mathbf{8 5}$ & $\mathbf{1 1 5 . 5}$ \\
\hline 0 & $6.9 \times 10^{5}$ & $7.3 \times 10^{5}$ & $9.4 \times 10^{4}$ & $9.4 \times 10^{4}$ \\
$15 \mathrm{~min}$ & $5.4 \times 10^{5}$ & $\mathrm{ND}$ & $\mathrm{ND}$ & $1.6 \times 10^{4}$ \\
$30 \mathrm{~min}$ & $4.5 \times 10^{5}$ & $1.35 \times 10^{5}$ & $7.1 \times 10^{3}$ & $8.0 \times 10^{2}$ \\
$45 \mathrm{~min}$ & $\mathrm{ND}$ & $\mathrm{ND}$ & $\mathrm{ND}$ & $2.0 \times 10^{1}$ \\
$1 \mathrm{~h}$ & $4.7 \times 10^{5}$ & $4.5 \times 10^{4}$ & $8.7 \times 10^{2}$ & $<1$ \\
$2 \mathrm{~h}$ & $3.0 \times 10^{5}$ & $5.0 \times 10^{4}$ & $3.5 \times 10^{2}$ & $<1$ \\
$3 \mathrm{~h}$ & $3.8 \times 10^{5}$ & $3.0 \times 10^{3}$ & $8.0 \times 10^{1}$ & $<1$ \\
$4 \mathrm{~h}$ & $\mathrm{ND}$ & $2.9 \times 10^{3}$ & $5.0 \times 10^{1}$ & $<1$ \\
$5 \mathrm{~h}$ & $3.0 \times 10^{5}$ & $1.4 \times 10^{3}$ & 2 & $<1$ \\
$10 \mathrm{~h}$ & $4.0 \times 10^{3}$ & $3.2 \times 10^{2}$ & $<1$ & $<1$ \\
\hline
\end{tabular}

Negative results from $10 \mathrm{~g}$ samples recorded as $<1$. CFU: Colony forming unit.

On the other hand, other studies have shown that survival of foodborne pathogens, such as Salmonella in powder milk remain for long period and resume growth when the milk powder is reconstituted and stored in favorable temperature and physical condition [22,23]. The drop in viable count was correlated closely with a rise in moisture up to about 15 to $20 \%$. Beyond $20 \%$ moisture in the products, a leveling off of destruction occurs with good growth beginning at 40\% [5].

Milk powder contaminated with Salmonella stored at different temperatures showed little reduction in the numbers of viable Salmonella in 15 weeks [5]. High storage temperature which destroyed Salmonella in powder would adversely affect flavor of the products [24]. Chances of survival of Salmonella increases as moisture and water activity $\left(\mathrm{a}_{\mathrm{w}}\right)$, and heat resistance increases during the drying process. Thus, Salmonella in dried milk is extremely heat resistant, with viable cells detected after $10 \mathrm{~h}$ at $76.6{ }^{\circ} \mathrm{C}[5-25]$.

Water activity $\left(\mathrm{a}_{\mathrm{w}}\right)$ of powdered milk is low, where moisture content of the products is deliberately reduced. Powder milk has the advantages of controlling the growth of pathogenic and spoilage microorganisms due to its low water activity and moisture content [1-3]. This is why fluid milk is dehydrated to control microbes for long storage.

On the other hand, [3] pointed out that water in low $a_{w}$ foods is in glassy and rubbery states, so that water has limited mobility which helps water molecules contact bacterial cells during their interaction. Thus, bacterial cells normally survive longer periods in dried food such as powder milk. 
In dehydrated foods including milk powder, survival of only few cells of some foodborne pathogens, e.g., Salmonella or Escherichia coli O157:H7, may be enough to cause diseases [1].

In vegetative cells of foodborne pathogens, bacterial and fungal spores may survive in foods and food ingredients with low water activity less than 0.85 for long periods [1]. In a recent study with skim milk powder, [3] showed that the level of water activity $\left(\mathrm{a}_{\mathrm{w}}\right)$ significantly influenced the survivability of Salmonella enteric. The survival of microorganisms was significantly $(p<0.05)$ higher at $\mathrm{a}_{\mathrm{w}} 0.33$, as compared to $\mathrm{a}_{\mathrm{w}} 0.53$ and $\mathrm{a}_{\mathrm{w}} 0.81$ (Figure 1). It was attributed to the fact that the reduction rate of viable cell counts at $\mathrm{a}_{\mathrm{w}}$ of $0.33,0.51$ and 0.81 at 2 months' storage at $37^{\circ} \mathrm{C}$ were $4.23,4.69$ and $5.85 \operatorname{logs}$ (colony-forming units $(\mathrm{CFU}) / \mathrm{g}$ ), respectively (Figure 1).

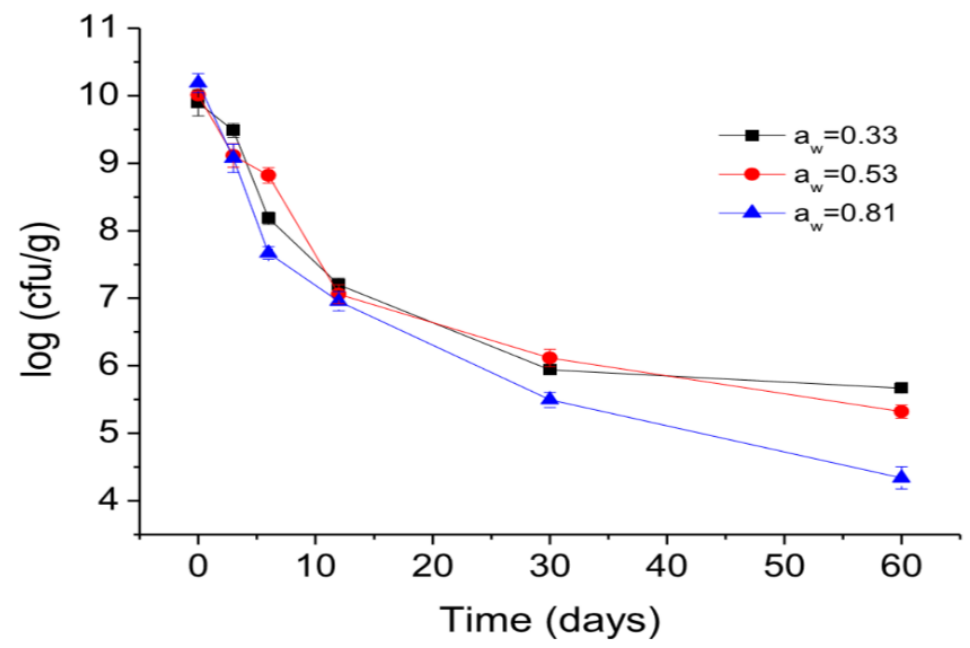

Figure 1. Survival of Salmonella enteric at $37^{\circ} \mathrm{C}$ and 3 water activities during 2 months of storage in skim milk powder. Adapted from [3].

\subsection{Survival of Escherichia coli O157:H7 in Dried Foods and Other Products}

Dry foods can be contaminated with pathogens, posing as vehicles for foodborne infection or outbreaks by the contaminated pathogenic organisms [1,2]. Bacterial cells that are in a state of desiccation have a slower rate of metabolism, and growth is halted, while vegetative cells can survive for many months or even years [1].

The survival of the pathogen is influenced by several factors, including temperature, number of cells, bacterial type or strain, stress from oxygen level, nutrient levels, and substrate [26]. Escherichia coli O157:H7 do not produce spores during stress, instead the organism changes its rate of metabolic or physiological activity [26]. Escherichia coli O157:H7 possibly even have the capability of avoiding food shortages by developing ways to utilize nutrients that are more readily available, instead of relying on the ideal nutrients that may not be present in sufficient amounts [26].

In order to ensure proper enumeration of viable Escherichia coli O157:H7 cells from dry foods, it is important to follow enrichment procedures along with direct plating methods for injured cells or decreased cell count [22]. Although most outbreaks associated with low water activity foods, the possibilities of cross contamination exist during manufacturing and processing. The survivability of Escherichia coli O157:H7 has been studied in some dried dairy products, such as buttermilk powder, sour cream powder, and powdered infant formula [11-22].

Viable cells of E. coli O157:H7 were found in storage up to 19 weeks in both buttermilk powder and sour cream powder stored at $5{ }^{\circ} \mathrm{C}$ [22]. Viable cells were found up to one year in powdered infant formula stored at $5{ }^{\circ} \mathrm{C}$ [11]. In previous studies, the survival of this pathogen in low water activity foods stored at higher temperatures from $21-22^{\circ} \mathrm{C}$ to $35-37^{\circ} \mathrm{C}$, was found to be greatly reduced when compared to the lower storage temperature of $5^{\circ} \mathrm{C}$ [11-22]. 


\section{Survival of Other Major Pathogens in Food Products}

\subsection{Listeria monocytogenes}

Listeria monocytogenes is common pathogen causing listeriosis, and it can survive and grow in a wide range of environmental conditions such as refrigeration temperatures, low $\mathrm{pH}$ and higher salt concentration [27]. Listeria monocytogenes also has survival capacity in different kind of low water-activity food, such as infant formula, dry milk powder, cocoa powder, wheat flour, almonds and pistachios, chicken meat powder etc. during extended storage periods [28]. The survival of L. monocytogenes in non-fat dry milk products stored at $4{ }^{\circ} \mathrm{C}$ and $22{ }^{\circ} \mathrm{C}$ for 1 year revealed that non-fat dry milk products could support the survival of L. monocytogenes at both temperatures, while at refrigerated temperature $\left(4^{\circ} \mathrm{C}\right)$ the pathogen showed higher survival rate as compared with storage at ambient temperature $\left(22{ }^{\circ} \mathrm{C}\right)$ [28]. Therefore, L. monocytogenes have the strength to survive in food products having low $\mathrm{a}_{\mathrm{w}}$ (water activity) such as dry milk for extended storage periods under refrigerated to ambient temperatures [11]. In yogurt and ice cream samples, Listeria monocytogenes also survived at $-18{ }^{\circ} \mathrm{C}$ for up to 30 days' of storage [29].

\subsection{Staphylococcus aureus}

Staphylococcus aureus is another most common food borne pathogens in the United States which causes staphylococcal food-borne diseases (SFD). Worldwide, SFD is also one of the most common food-borne diseases resulting from the contamination of food by S. aureus [30].

\subsection{Other Pathogens in Low Water-Activity Foods}

The survival of other foodborne bacterial pathogens in various powdered milk products has been studied, including Cronobacter sakazakii [3-11]. The survival of viable bacterial cells was also studied for C. sakazakii with the major pathogens (L. monocytogenes, E. coli O157:H7, and Salmonella enterica) in powdered infant formula $\left(\mathrm{a}_{\mathrm{w}} 0.28\right)$, for one year storage at $5{ }^{\circ} \mathrm{C}$ [11].

\section{Salmonella Outbreaks Studies in Milk and Dairy Products}

The occurrence of sicknesses due to contamination with Salmonella has long been recognized as a global health problem. Pal et al., 2016 [23] mentioned that every year globally about 93.8 million cases of gastroenteritis and 155,000 deaths caused by Salmonella infections. Large numbers of outbreaks of foodborne illness caused by Salmonella are due to consumption of dry foods and food ingredients' contamination, where out of 33 listed outbreak 27 were caused by Salmonella [31].

Marth, 1969 [32] reported, during the 1950s, a number of outbreaks of Salmonella due to consumption of dried milk: in Britain 12 cases of salmonellosis in 1950 with the consumption of dried milk contaminated with S. typhimurium, in Bulgaria during the 1945-1950 outbreak of salmonellosis-contaminated dried milk were recorded and in the United State 2 cases gastroenteritis outbreaks occurred resulting from the dried milk contaminated with Salmonella.

A total number of 3000 affected cases by outbreak of Salmonella Derby in Trinidad in 1973 were due to imported dried milk products [33]. Moreover, during 1984-1985 a state and federal health agencies investigation showed that $2 \%$ low-fat milk from a northern Illinois dairy processing plant caused one of the largest outbreaks of salmonellosis recorded in the United States [34]. A recent French study indicated that two or more outbreaks have occurred in the past 10 years [35]. An outbreak in 1990 (277 cases) of salmonellosis was possibly related to contaminated goat's milk cheese [35]. The consumption of old milk powder contained Salmonella aureus infected 150 people in China in 2004 [31].

A large number of outbreaks were reported in the past with different contaminated cheeses in different parts of world: outbreaks of Salmonella dublin infection occurred in England and Wales in 1989 with consumption of contaminated Irish soft unpasteurized cow milk cheese, and an outbreak of Salmonella enterica occurred in France in 2006 due to consumption of contaminated raw milk cheese. 
In Canada, during the autumn of 1941 an epidemic of typhoid fever occurred after consumption of cheddar cheese made from raw milk, similar outbreak was recorded in Quebec during February 1944 [36,37]. Recent study in France, 22 cases of Salmonella agona infection outbreak were identified among infants younger than six months from consumption of infant milk products [38].

\section{Escherichia coli O157:H7 Outbreaks Studies in Milk and Dairy Products}

Chekabab et al., 2013 [26] reported that Escherichia coli O157:H7 do not produce spores during stress, instead this pathogen organism changes its rate of metabolic or physiological activity. These microorganisms possibly even have the capability of avoiding food shortages by developing alternative ways to utilize the nutrients which are more readily available, instead of relying on the ideal nutrients that may not be available in sufficient amounts [26].

Although most Escherichia coli O157:H7 outbreaks associated with low water-activity foods have not been linked to dried dairy products, the survival of bacterial organisms in the dried dairy products is still being investigated because the possibilities of cross contamination exist during manufacturing and processing. Escherichia coli O157:H7 survival studies have been conducted in some dried dairy products, such as buttermilk powder, sour cream powder, and powdered infant formula [11-22]. In low water activity foods, Escherichia coli O157:H7 survival rate was lower at higher temperatures such as room temperature $\left(21^{\circ} \mathrm{C}-22^{\circ} \mathrm{C}\right)$ than at the lower storage temperature of $5{ }^{\circ} \mathrm{C}$ such as under refrigeration [22].

With injured cells or decreased cell count, it is important to follow enrichment methods along with direct plating methods to ensure proper enumeration of viable Escherichia coli O157:H7 cells from dry foods [22]. The previous studies [11-22] have demonstrated that the survival of this pathogen in low water-activity foods stored at higher temperatures from $21-22^{\circ} \mathrm{C}$ to $35-37^{\circ} \mathrm{C}$, was found to be greatly reduced when compared to the lower storage temperature of $5^{\circ} \mathrm{C}$.

In other types of dairy product, Govaris et al., 2002 [39] observed that E. coli 0157:H7 survived in acidic ( $\mathrm{pH}<4.5)$ environment of feta and brine cheese, and also the pathogens survived maximum days for cheese samples stored at $4{ }^{\circ} \mathrm{C}$ compared to at $12{ }^{\circ} \mathrm{C}$. A similar study observed that $E$. coli O157:H7 had a great potential to survive in white brined cheese at $10^{\circ} \mathrm{C}$ and $21^{\circ} \mathrm{C}$ for 20 days [9]. Survival of E. coli O157:H7 was also observed in yogurt, however E. coli O157:H7 survived significantly lower at $4{ }^{\circ} \mathrm{C}$ as compared to sample storage at $22^{\circ} \mathrm{C}$ [40].

\section{Stability of Dehydrated Milk Products during Storage Treatments}

\subsection{Stability of Powdered Milk during Storage}

Storage condition is considered one of the major factors affecting quality and stability of powder milk products. Quality of powder milk during storage is determined by the manufacturing and drying techniques of milk [17]. According to the standards of the United States Dairy Export Council (2005), milk powder should be stored in cool and dry environment at temperature less than $27^{\circ} \mathrm{C}$ and relative humidity less than $65 \%$. In addition, milk powder needs to be stored in a light, oxygen and moisture-proof container, and maintaining these condition can extend storage life up to 6-9 months.

Dehydration of fluid milk reduces the moisture of the milk, which controls the growth of microbes and slows down the unfavorable physical and chemical changes in the products [41]. The physical changes that occur in milk powder can include increased cohesion and caking, while Maillard reactions and the oxidation of lipids are the two major concerns for chemical changes that occur in milk powders [17].

The non-enzymatic browning, Maillard reaction, is a chemical reaction that occurs among reducing sugars, such as lactose, and amino acids, resulting in a brown coloring of the food product [42]. The rate of Maillard reactions depend on different storage conditions, such as humidity level, temperature, and the manufacturing methods used to produce the milk powder [17]. These reactions can change the 
nutritional and organoleptic qualities of the powder milk products through the decrease in lysine and development of brown colors and loss of flavor, respectively [43].

An increase in fatty acid content of whole milk powder can occur due to the breakdown of fatty acids from triglycerides, caused by moisture content in the product during storage at $4{ }^{\circ} \mathrm{C}$ and $27^{\circ} \mathrm{C}$ for six months [44]. In a storage study of whole milk powder at $2{ }^{\circ} \mathrm{C}$ or $23{ }^{\circ} \mathrm{C}$ with $50 \%$ relative humidity for 12 months, [45] found higher peroxide values in powdered milk packaged with air than with nitrogen, whereas no difference was found between the two storage temperatures.

There was no change in moisture content during six months' storage at $25^{\circ} \mathrm{C}$ of whole goat milk powder due to efficient packaging [46]. There was a gradual increase in peroxide value in the stored whole goat milk powder, as well as an increase linearly in the caprylic (C8) and capric (C10) free fatty acids during the storage of the whole goat milk powder [47]. Romeu-Nadal et al., 2007 [48] also observed that whole milk powder stored at $20^{\circ} \mathrm{C}$ showed a gradual increase in peroxide value or lipid oxidation during storage for 24 months.

The storage stability of powdered goat milk (PGM) was affected by two temperatures and 4 month storage treatments [4]. Storage temperature had a minimal effect on the fatty acid profiles in the PGM samples. On the other hand, storage time had a significant $(p<0.05)$ influence on $\mathrm{pH}$, lipid oxidation, and fatty acid profiles of the PGM products [4].

\subsection{Lipid Oxidation and Lipolysis of Powder Milk}

Lipid oxidation has received a great attention on the quality of powder products because of its undesirable implications in human health due to the deterioration in the nutritional value of milk fat. Lipid oxidation is the process of oxidative degradation of lipids if foods followed by a mechanism of free radical formation to produce hydro-peroxides, called primary oxidation products, which then are broken to produce off-flavor compounds [49]. In addition, it is detrimental to the dairy industries because of its negative influence on the shelf life of milk powder products [15-45].

The primary oxidation products further go on lipid oxidation and give rise to the secondary oxidation products including alkanes, alkenes, aldehydes, ketones, epoxides, volatile organic acids and alcohol [15-50]. These compounds are attributed to off-flavors, causing loss of nutrients in milk powders, and result in reduced storage stability [15-51]. The rate of lipid oxidation in milk powder is influenced by several factors such as oxygen, exposure to ultraviolet (UV)-light, temperature, moisture, water activity and composition of unsaturated fatty acids [42-52].

Milk powder can become rancid as a consequence of it lipid oxidation and lipolysis. This oxidative rancidity is a major cause for the changes in sensory properties of milk powder [53,54]. Light is one of the major factors that greatly influence the rate of lipid oxidation, which creates serious problems for the dairy industry due to the development of off-flavors and reduce the nutritional quality [15-52]. Increases in lipid oxidation of milk powder cause unfavorable changes in flavor, color, taste and loss of vitamins [15-55].

Several methods are used for measuring lipid oxidation, such as peroxide value, thiobarbituric acid test (TBA), $p$-anisidine value, total carbonyls, chromatographic method, oil stability index, kreis test and fluorescence assays [42-55]. Hydroperoxides is the primary products and because of its instability, it undergoes further oxidation to give rise to secondary products of lipid oxidation, which are measured by other methods except peroxide value [55].

High fat-containing powdered milk products have an increased risk of changes in sensory properties by oxidative reactions that can cause rancid or off flavors [15]. Food, especially milk products, when exposed to light, undergoes several changes. An example is the increase in lipid oxidation, which causes unfavorable changes in flavor, color, and a reduction in vitamin levels [15-56].

Several methods are available for measuring the oxidation of lipids. Peroxide values can be measured through different methods: iodometric titration method, ferric ion complexes, and Fourier transform infrared spectroscopy [55]. Conjugated dienes and trienes levels can be measured through the use of ultraviolet spectrometry [55]. Because of the instability of these hydroperoxides, there are 
methods available to measure the secondary products of lipid oxidation: thiobarbituric acid test (TBA), $p$-anisidine value, ToTox value (ToTox value means $\mathrm{AV}+2 \mathrm{PV}$, where $\mathrm{AV}$ is anisidine value and $\mathrm{PV}$ is peroxide value), total carbonyls, oil stability index, hydrocarbons via gas chromatography, and fluorescence assays [55].

\section{Recent Studies on Survivability of Salmonella and Escherichia coli Pathogens in Powdered Goat Milk Products}

\subsection{Survivability of Salmonella Pathogens in Powdered Goat's Milk}

Food stability, safety, and other properties can be predicated reliably better by water activity $\left(\mathrm{a}_{\mathrm{W}}\right)$ than from water content [42]. In a very recent study on the survivability of Salmonella pathogens and the storage stability of commercial powdered goat milk (PGM) products, [56] found that significant differences in $\mathrm{a}_{\mathrm{w}}$ between storage temperature (ST) at the beginning of the 6-month storage experiment (Figure 2), and batch (B), storage period (SP), and their interaction effects were not significant in 6-month storage of PGM samples.

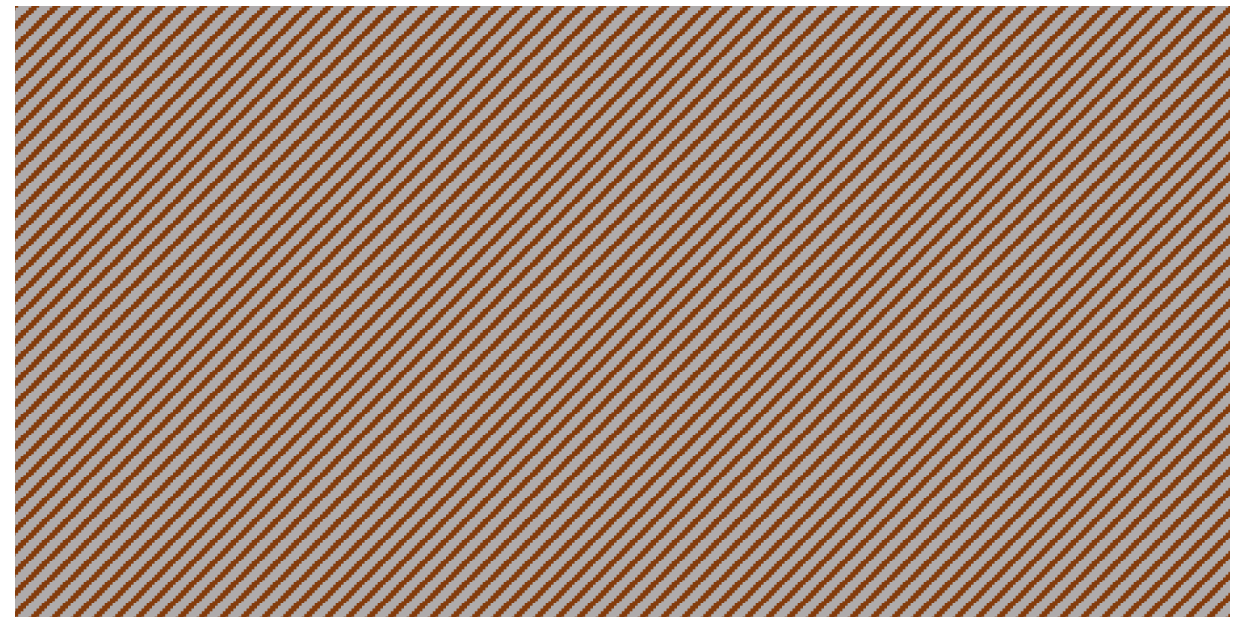

Figure 2. A,B Bars with different letters at 0 month are significantly different $(p<0.05)$. Comparison of water activity in powdered goat milk samples stored at 4 and $25^{\circ} \mathrm{C}$ for 0,2 , and 4 months storage (adapted from [56]).

In the same study, Paswan et al., 2020 [56] found that there were significant $(p<0.01)$ differences in the peroxide value (POV) among SP, and $\mathrm{B} \times \mathrm{SP}, \mathrm{SP} \times \mathrm{ST}$ and $\mathrm{B} \times \mathrm{ST} \times \mathrm{SP}$ interaction effects. The experimental goat powder samples stored at $25^{\circ} \mathrm{C}$ showed higher POV values than those stored at $4{ }^{\circ} \mathrm{C}$. The POVs of PGM revealed significant $(p<0.01)$ differences between storage periods, indicating that the rate of lipid oxidation of the PGM samples was elevated with the advanced storage periods (Figure 3).

Paswan et al., 2020 [56] reported that the non-linear regression survival curves by Weibull model using the Integrated Pathogen Modeling Program 2013 (Huang, 2014) [57] revealed that the survival kinetics of Salmonella in the 3 batches of powder goat milk stored at $4{ }^{\circ} \mathrm{C}$ for 180 days showed a gradual decrease throughout the storage period (Figure 4). Compared to the bacterial counts of the experimental commercial powdered goat milk samples stored at $4{ }^{\circ} \mathrm{C}$ for 180 days storage, the survival of Salmonella bacterial counts (CFU/g) were lower at $25^{\circ} \mathrm{C}$ treated samples. However, the overall trend of the survivability of Salmonella pathogen counts (CFU/g) in the commercial powdered goat milk samples for 6-month storage were similar across batches and across temperature treatment groups [56].

As far as Salmonella studies in cow milk powder products go, Lian et al., 2015 [3] reported that Salmonella enterica skim milk survived at three months storage with as low as 0.33 water activity. Salmonella species have frequently been reported as concerned pathogens in contamination of low-moisture food products [2]. 


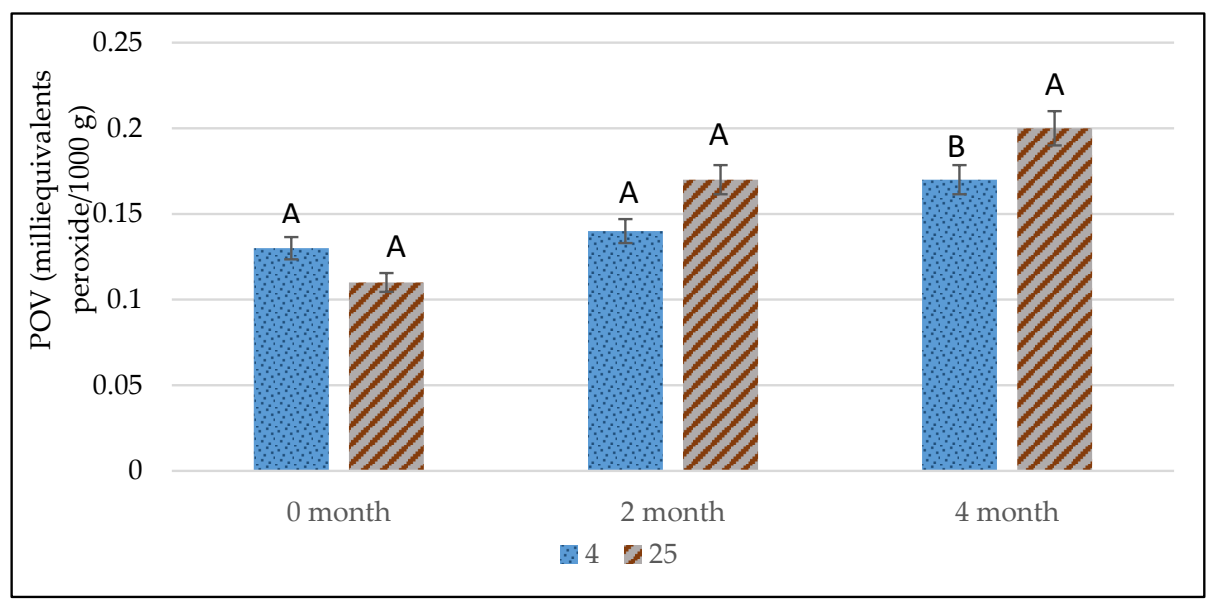

Figure 3. A,B Bars with different letters at 4 month are significantly different $(p<0.05)$. Comparison of peroxide values of experimental powder goat milk stored at 4 and $25^{\circ} \mathrm{C}$ for 0,2 and 4 months (adapted from [56]).

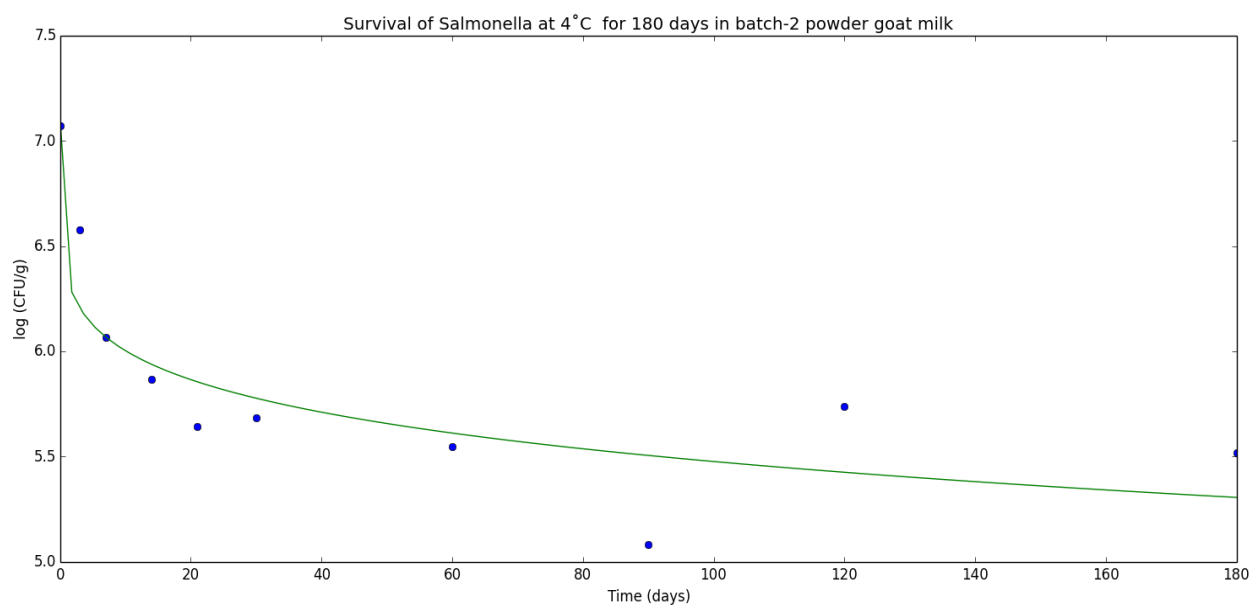

Figure 4. Weibull model curve showing the mean value of batch 2 of powdered goat milk (PGM) on the survivability of Salmonella at $4{ }^{\circ} \mathrm{C}$ for 180 days using IPMP 2013. (Adapted from [56]).

\subsection{Survivability of Escherichia coli Pathogens in Powdered Goat Milk Products}

A significant decrease in E. coli counts was observed in room temperature $\left(22^{\circ} \mathrm{C}\right)$ group [4]. Samples stored at $22^{\circ} \mathrm{C}$ showed a reduction of E. coli by more than $2 \log \mathrm{CFU} / \mathrm{g}$ at two months storage and continuously decreased by additional $0.37 \log \mathrm{CFU} / \mathrm{g}$ at four months storage. The survival of the E. coli bacteria was significantly higher at $4{ }^{\circ} \mathrm{C}$ storage than $22^{\circ} \mathrm{C}$ storage temperature, suggesting that $E$. coli could survive better in low temperature by extending a longer latent period than higher $\left(22^{\circ} \mathrm{C}\right)$ temperature with the same low water activity $\left(\mathrm{a}_{\mathrm{w}}=0.2\right)$ condition (Figure 5$)$. The survivability of Escherichia coli in the PGM samples was significantly reduced with the synergistic effects of storage time and storage temperature.

Davis et al., 2018 [4] found that there were significant gradual decreases in Escherichia coli counts during 0,2 , and 4 months storage of the commercial PGM samples (Figure 5). On the other hand, there were slight decreases in water activity for both temperature treatments except at $4{ }^{\circ} \mathrm{C}$ for a 4 -month period, which resulted in negative correlations ( $\mathrm{r}$ ) between $E$. coli counts and water activity at both temperature treatments for all three storage periods $(0,2$, and 4 months) except for 0 and 2 months at $22{ }^{\circ} \mathrm{C}$ (Table 2). For higher temperature $\left(22{ }^{\circ} \mathrm{C}\right)$, the $r$ value during 4 months was negative and significant $(p<0.05)$, while $r$ values at 0 and 2 weeks storage were not significant (Table 2). These correlation data may indicate that the survivability of the $E$. coli would decrease in the commercial 
powdered whole goat milk during 4 months' of storage, as the water activity (water content) decreased for the prolonged storage period.

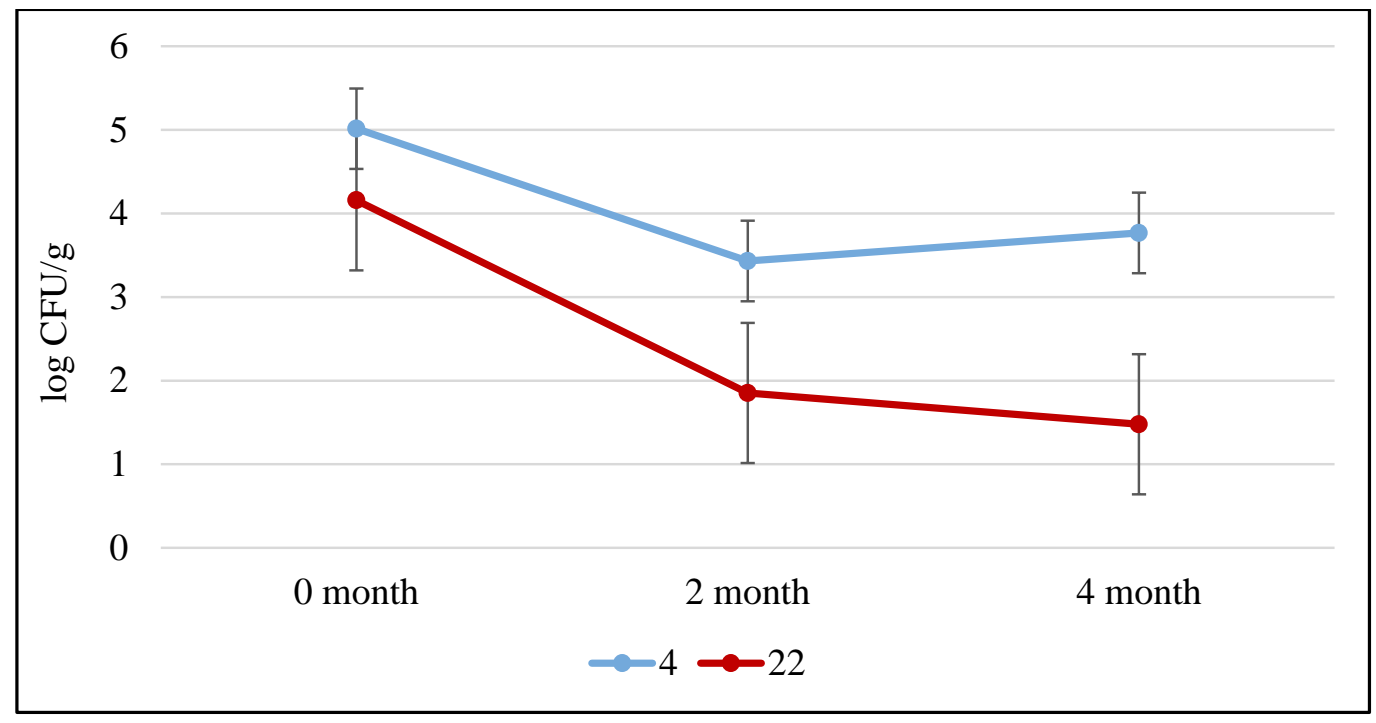

Figure 5. Comparison of the survival of Escherichia coli (log colony-forming units (CFU)/g) counts in powder whole goat milk stored for four months at $4{ }^{\circ} \mathrm{C}$ and $22{ }^{\circ} \mathrm{C}$ (adapted from [4]).

Table 2. Correlation coefficients between E. coli count and water activity in powder goat milk during 0 , 2 , and 4 months storage at 4 and $22{ }^{\circ} \mathrm{C}$ (adapted from [4]).

\begin{tabular}{ccccccc}
\hline & \multicolumn{2}{c}{ E. coli Count Month 0 } & \multicolumn{2}{c}{ E. coli Count Month 2 } & \multicolumn{2}{c}{ E. coli Count Month 4} \\
\hline Water & $4{ }^{\circ} \mathrm{C}$ & $22{ }^{\circ} \mathrm{C}$ & $4{ }^{\circ} \mathrm{C}$ & $22{ }^{\circ} \mathrm{C}$ & $4{ }^{\circ} \mathrm{C}$ & $22{ }^{\circ} \mathrm{C}$ \\
Activity & -0.574 & 0.404 & -0.644 & 0.346 & -0.345 & $-0.8544^{*}$ \\
\hline
\end{tabular}

* Significant at $p<0.05$.

Although most outbreaks associated with low water-activity foods have not been linked to dried dairy products, the survival of bacterial organisms in these dried dairy products is still being investigated because the possibilities of cross contamination exist during manufacturing and processing. Escherichia coli O157:H7 survival studies have been conducted in some dried dairy products, such as buttermilk powder, sour cream powder, and powdered infant formula [11-22].

Deng et al., 1998 [22] observed that viable cells of Escherichia coli O157:H7 were found in storage up to 19 weeks in both buttermilk powder and sour cream powder stored at $5{ }^{\circ} \mathrm{C}$. In addition, Koseki et al., 2015 [11] also showed that viable cells of Escherichia coli O157:H7 were found in powdered infant formula stored at $5{ }^{\circ} \mathrm{C}$, up to one year. This trend of survival of Escherichia coli O157:H7 in powdered infant formula in low storage temperature was in agreement with the findings of Davis et al., 2018 [4] in powdered goat milk products.

\section{Conclusions}

Milk and its products are the most frequently contaminated foods by Salmonella, where Salmonella, Escherichia coli O157:H7 and Listeria monocytogenes, Campylobacter jejuni, and Clostridium botulinum are among the top 5 pathogens causing foodborne illnesses. Salmonella can survive and grow in a wide range of environmental conditions such as refrigeration temperatures, low $\mathrm{pH}$ and higher salt concentration and even in dehydrated foods. The survival of the pathogens is influenced by the number of cells, bacterial type or strain, stress from oxygen level, moisture content, nutrient levels, and substrate, etc. 
Escherichia coli O157:H7 does not produce spores during stress; instead, the organism changes its rate of metabolic or physiological activity. E. coli O157:H7 possibly even have the capability of avoiding food shortage by developing ways to utilize the nutrients more readily available, instead of relying on the ideal nutrients that may not be present in sufficient amounts.

Food stability and safety can be more reliably predicted by water activity $\left(\mathrm{a}_{\mathrm{w}}\right)$ than from water content. Recent studies showed the survivability of Salmonella and Escherichia coli O157:H7 in powdered goat milk products was significantly reduced with the synergistic effects of storage time and storage temperature. In order to maintain the storage stability of powdered milk products, as well as to minimize the survivability of Salmonella and Escherichia coli O157:H7, they need to be stored in a light, oxygen- and moisture-proof container at low temperature (i.e., $<4{ }^{\circ} \mathrm{C}$ ), and maintaining these conditions can extend the storage life of dehydrated products.

Author Contributions: Conceptualization, Y.W.P.; methodology, Y.W.P. and R.P.; validation, Y.W.P. and R.P.; formal analysis, Y.W.P. and R.P.; investigation, Y.W.P. and R.P.; resources, Y.W.P.; writing-original draft preparation, Y.W.P. and R.P.; writing-review and editing, Y.W.P.; supervision, Y.W.P.; project administration, Y.W.P.; funding acquisition, Y.W.P. All authors have read and agreed to the published version of the manuscript.

Funding: This research was funded by the grants of NIFA/USDA Evans-Allen funds of GEOX-3225.

Conflicts of Interest: The authors declare no conflict of interest.

\section{References}

1. Beuchat, L.; Komitopoulou, E.; Beckers, H.; Betts, R.; Bourdichon, F.; Fanning, S.; Joosten, H.; Ter Kuile, B. Low-Water Activity Foods: Increased Concern as Vehicles of Foodborne Pathogens. J. Food Prot. 2013, 76, 150-172. [CrossRef] [PubMed]

2. Finn, S.; Condell, O.; McClure, P.; Amézquita, A.; Fanning, S. Mechanisms of survival, responses, and sources of Salmonella in low-moisture environments. Front. Microbiol. 2013, 4, 331. [CrossRef] [PubMed]

3. Lian, F.; Zhao, W.; Yang, R.J.; Tang, Y.; Katiyo, W. Survival of Salmonella enteric in skim milk powder with different water activity and water mobility. J. Food Cont. 2015, 47, 1-6. [CrossRef]

4. Davis, B.I.; Siddique, A.; Mahapatra, A.K.; Park, Y.W. Survivability of Escherichia coli in commercial powder goat milk during four months storage at two different temperatures. Adv. Dairy Res. 2018, 6, 200. [CrossRef]

5. McDonough, F.E.; Hargrove, R.E. Heat resistance of Salmonella in dried milk. J. Dairy Sci. 1968, 51, $1587-1591$. [CrossRef]

6. Mazurek, J.; Salehi, E.; Propes, D.; Holt, J.O.; Bannerman, T.; Nicholson, L.M.; Bundesen, M.; Duffy, R.; Moolenaar, R.L. A multistate outbreak of Salmonella enterica serotype Typhimurium infection linked to raw milk consumption-Ohio, 2003. J. Food Prot. 2004, 67, 2165-2170. [CrossRef]

7. Hall, H.E.; Brown, D.F.; Robinson, H.M.; Donnelly, C.B.; Reyes, A.L. Bacteriological examination of grade A dry milk powder. J. Milk Food Tech. 1967, 30, 219-221. [CrossRef]

8. Montville, T.J.; Matthews, K.R. Food Microblogy: An Introduction; ASM Press: Washington, DC, USA, 2005; pp. 112-116.

9. Osaili, T.M.; Al-Nabulsi, A.A.; Olaimat, A.N.; Shaker, R.R.; Taha, M.; Holley, R.A. Survival of Escherichia coli O157: H7 during manufacture and storage of white brined cheese. J. Food Sci. 2014, 79, M1750-M1755. [CrossRef]

10. Kiranmayi, C.; Krishnaiah, N.; Mallika, E. Escherichia coli O157:H7-An Emerging Pathogen in Foods of Animal Origin. Vet. World 2010, 3, 382-389. [CrossRef]

11. Koseki, S.; Nakamura, N.; Shiina, T. Comparison of Dessication Tolerance among Listeria monocytogenes, Escherichia coli O157:H7, Salmonella enterica, and Cronobacter sakazakii in Powdered Infant Formula. J. Food Prot. 2015, 78, 104-110. [CrossRef]

12. Farrokh, C.; Jordan, K.; Auvray, F.; Glass, K.; Oppegaard, H.; Raynaud, S.; Thevenot, D.; Condron, R.; De Reu, K.; Govaris, A.; et al. Review of Shiga-toxin-producing Escherichia coli (STEC) and their significance in dairy production. Int. J. Food Microbiol. 2013, 162, 190-212. [CrossRef] [PubMed]

13. Kajal, M.F.I.; Wadud, A.; Islam, M.N.; Sarma, P.K. Evaluation of Some Chemical Parameters of Powder Milk Available in Mymensingh Town. J. Bangladesh Agril. Univ. 2012, 10, 95-100. [CrossRef] 
14. United States Dairy Export Council (USDEC) 2005. Reference Manual for U.S. Milk Powders: 2005 Revised Edition. 12, 36. Available online: http://www.thinkusadairy.org/resources-and-insights/resources-andinsights/product-resources/reference-manual-for-us-milk-powders (accessed on 3 January 2016).

15. Tehrany, E.; Sonneveld, K. Packaging and the Shelf Life of Milk Powders. In Food Packaging and Shelf Life, a Practical Guide; CRC Press: Boca Raton, FL, USA; London, UK, 2010; pp. 127-141.

16. Bryan, F.L. Epidemiology of milk-borne diseases. J. Food Prot. 1983, 46, 637-649. [CrossRef]

17. Oliver, S.; Jayarao, B.; Almeida, R. Foodborne Pathogens in Milk and the Dairy Farm Environment: Food Safety and Public Health Implications. Foodborne Pathog. Dis. 2005, 2, 115-129. [CrossRef]

18. Afroz, H.; Sultana, F.; Fakruddin, M.; Khan, M.; Uddin, Z.; Datta, S. Isolation of Escherichia coli and Staphylococcus aureus from Full Cream Powder Milk Sold under Market Conditions at Dhaka, Bangladesh and Their Antibiotic Susceptibility. J. Adv. Sci. Res. 2013, 4, 27-31.

19. Jayarao, B.M.; Donaldson, S.C.; Straley, B.A.; Sawant, A.A.; Hegde, N.V.; Brown, J.L. A survey of foodborne pathogens in bulk tank milk and raw milk consumption among farm families in Pennsylvania. J. Dairy Sci. 2006, 89, 2451-2458. [CrossRef]

20. Boor, K.J.; Wiedmann, M.; Murphy, S.; Alcaine, S. A 100-year review: Microbiology and safety of milk handling. J. Dairy Sci. 2017, 100, 9933-9951. [CrossRef]

21. Sheen, S.; Huang, L.; Sommers, C. Survival of Listeria monocytogenes, Escherichia coli O157: H7, and Salmonella spp. on catfish fillets exposed to microwave heating in a continuous mode. J. Food Sci. 2012, 77, E209-E214. [CrossRef]

22. Deng, Y.; Ryu, J.H.; Beuchat, L.R. Influence of temperature and pH on survival of Escherichia coli O157:H7 in dry foods and growth in reconstituted infant rice cereal. Int. J. Food Microbiol. 1998, 45, 173-184. [CrossRef]

23. Pal, M.; Alemu, J.; Mulu, S.; Karanfil, O.; Parmar, B.C.; Nayak, J.B. Microbial and hygienic aspects of dry milk powder. J. Bev. Food World 2016, 7, 28-31.

24. Keogh, B.P. Bacteriology. The survival of pathogens in cheese and milk powder. J. Dairy Res. 1971, 38, 91-111. [CrossRef] [PubMed]

25. Doyle, M.E.; Mazzotta, A.S. Review of studies on the thermal resistance of Salmonellae. J. Food Prot. 2000, 63, 779-795. [CrossRef] [PubMed]

26. Chekabab, S.; Paquin-Veillette, J.; Dozois, C.; Harel, J. The ecological habitat and transmission of Escherichia coli O157:H7. FEMS Microbiol. Lett. 2013, 341, 1-12. [CrossRef] [PubMed]

27. Mead, P.S.; Slutsker, L.; Dietz, V.; McCaig, L.F.; Bresee, J.S.; Shapiro, C.; Tauxe, R.V. Food-related illness and death in the United States. Emerg. Infect. Dis. 1999, 5, 607. [CrossRef] [PubMed]

28. Ballom, K.F.; Tsai, H.C.; Taylor, M.; Tang, J.; Zhu, M.J. Stability of Listeria monocytogenes in non-fat dry milk powder during isothermal treatment and storage. Food Microb. 2020, 87, 103376. [CrossRef] [PubMed]

29. El shinaway, S.H.; Meshref, A.M.S.; Zeinhom, M.M.A.; Hafez, D.A. The Survival of Listeria Monocytogenes in Yoghurt and Ice Cream. J. Vet. Med. Res. 2017, 24, 235-246. [CrossRef]

30. Kadariya, J.; Smith, T.C.; Thapaliya, D. Staphylococcus aureus and staphylococcal food-borne disease: An ongoing challenge in public health. BioMed Res. Inter. 2014. [CrossRef]

31. Beuchat, L.; Komitopoulou, E.; Betts, R.; Beckers, H.; Bourdichon, F.; Joosten, H.; ter Kuile, B. Persistence and Survival of Pathogens in Dry Foods and Dry Food Processing Environments; ILSI Europe Report Series; International Life Sciences Institute: Washington, DC, USA, 2011.

32. Marth, E.H. Salmonellae and salmonellosis associated with milk and milk products. A review. J. Dairy Sci. 1969, 52, 283-315. [CrossRef]

33. Weissman, J.B.; Deen, R.M.A.D.; Williams, M.; Swanston, N.; Ali, S. An island-wide epidemic of salmonellosis in Trinidad traced to contaminated powdered milk. West Indian Med. J. 1977, 26, 135-143.

34. Ryan, C.A.; Nickels, M.K.; Hargrett-Bean, N.T.; Potter, M.E.; Endo, T.; Mayer, L.; Langkop, C.W.; Gibson, C.; McDonald, R.C.; Kenney, R.T.; et al. Massive outbreak of antimicrobial-resistant salmonellosis traced to pasteurized milk. JAMA 1987, 258, 3269-3274. [CrossRef]

35. Desenclos, J.C.; Bouvet, P.; Benz-Lemoine, E.; Grimont, F.; Desqueyroux, H.; Rebiere, I.; Grimont, P.A. Large outbreak of Salmonella enterica serotype paratyphi B infection caused by a goats' milk cheese, France, 1993: A case finding and epidemiological study. BMJ 1996, 312, 91-94. [CrossRef] [PubMed]

36. Maguire, H.; Cowden, J.; Jacob, M.; Rowe, B.; Roberts, D.; Bruce, J.; Mitchell, E. An outbreak of Salmonella dublin infection in England and Wales associated with a soft unpasteurized cows' milk cheese. Epidemiol. Infect. 1992, 109, 389-396. [CrossRef] [PubMed] 
37. Dominguez, M.; Jourdan-Da Silva, N.; Vaillant, V.; Pihier, N.; Kermin, C.; Weill, F.X.; Delmas, G.; Kerouanton, A.; Brisabois, A.; de Valk, H. Outbreak of Salmonella enterica serotype Montevideo infections in France linked to consumption of cheese made from raw milk. Foodborne Pathog. Dis. 2009, 6, 121-128. [CrossRef]

38. Jourdan-da, N.S.; Fabre, L.; Robinson, E.; Fournet, N.; Nisavanh, A.; Bruyand, M.; Issenhuth-Jeanjean, S. Ongoing nationwide outbreak of Salmonella Agona associated with internationally distributed infant milk products, France, December 2017. Eurosurveillance 2018, 23, 17-00852. [CrossRef]

39. Govaris, A.; Koidis, P.; Papatheodorou, K. Survival of Escherichia coli 0157: H7 in Feta cheese during storage. J. Hell. Vet. Med. Soc. 2002, 53, 24-32. [CrossRef]

40. Akdemir Evrendilek, G.Ü.L.S.Ü.N. Survival of Escherichia coli O157: H7 in yogurt drink, plain yogurt and salted (tuzlu) yogurt: Effects of storage time, temperature, background flora and product characteristics. Int. J. Dairy Technol. 2007, 60, 118-122. [CrossRef]

41. Rehman, S.U.; Farkye, N.; Schaffner, A. The Effect of Multiwall Kraft Paper or Plastic Bags on Physico-chemical Changes in Milk Powder during Storage at High Temperature and Humidity. Int. J. Dairy Technol. 2003, 56, 12-16. [CrossRef]

42. Fennema, O.R. Food Chemistry, 3rd ed.; Marcel Dekker Inc.: New York, NY, USA, 1996; pp. 255-299.

43. Schuck, P.; le Floch-Fouere, C.; Jeantet, R. Changes in Functional Properties of Milk Protein Powders: Effects of Vacuum Concentration and Drying. Dry. Technol. 2013, 31, 1578-1591. [CrossRef]

44. Tamsma, A.; Kontson, A.; Kurtz, F.E. Relationships between Volatile Compounds, Storage Conditions Deodorization, and Flavor Scores of Milk Fats and Dry Whole Milks. J. Dairy Sci. 1974, 57, 1143-1148. [CrossRef]

45. Lloyd, M.A.; Drake, M.A.; Gerard, P.D. Flavor variability and flavor stability of US-produced whole milk powder. J. Food Sci. 2009, 74, S334-S343. [CrossRef]

46. Fonseca, C.R.; Bordin, K.; Fernandes, A.M.; Rodrigues, C.E.C.; Corassin, C.H.; Cruz, A.G.; Oliveira, C.A.F. Storage of Refrigerated Raw Goat Milk Affecting the Quality of Whole Milk Powder. J. Dairy Sci. 2013, 96, 4716-4724. [CrossRef] [PubMed]

47. Chudy, S.; Pikul, J.; Rudzińska, M. Effects of storage on lipid oxidation in milk and egg mixed powder. J. Food Nut. Res. 2015, 54, 31-40.

48. Romeu-Nadal, M.; Chavez-Servin, J.L.; Castellote, A.I.; Rivero, M.; Lopez-Sabater, M.C. Oxidation stability of the lipid fraction in milk powder formulas. Food Chem. 2007, 100, 756-763. [CrossRef]

49. Barriuso, B.; Astiasarán, I.; Ansorena, D. A review of analytical methods measuring lipid oxidation status in foods: A challenging task. Eur. Food Res. Technol. 2013, 236, 1-15. [CrossRef]

50. Fenaille, F.; Visani, P.; Fumeaux, R.; Milo, C.; Guy, P.A. Comparison of mass spectrometry-based electronic nose and solid phase microextraction gas chromatography mass spectrometry technique to assess infant formula oxidation. J. Agric. Food Chem. 2003, 51, 2790-2796. [CrossRef] [PubMed]

51. Park, Y.W. Proteolysis and lipolysis of goat milk cheese. J. Dairy Sci. 2001, 84, E84-E92. [CrossRef]

52. Gray, J.I. Measurement of lipid oxidation: A review. J. Am. Oil Chem. Soc. 1978, 55, 539-546. [CrossRef]

53. Park, Y.W.; Gerard, P.D.; Drake, M.A. Impact of frozen storage on flavor of caprine milk cheeses. J. Sens. Stud. 2006, 21, 654-663. [CrossRef]

54. Shahidi, F.; Zhong, Y. Lipid Oxidation: Measurement Methods. In Bailey's Industrial Oil and Fat Products, 6th ed.; Shahidi, F., Ed.; John Wiley \& Sons Inc.: Newfoundland, CA, USA, 2005; pp. 357-385.

55. Wąsowicz, E.; Gramza, A.; Hęś, M.; Jeleń,H.H.; Korczak, J.; Malecka, M.; Mildner-Szkudlarz, S.; Rudzińska, M.; Samotyja, U.; Zawirska-Wojtasiak, R. Oxidation of Lipids in Food. Pol. J. Food Nutr. Sci. 2004, 13, 87-100.

56. Paswan, R.; Mishra, A.; Park, Y.W. Survivability of Salmonella pathogens in powder goat milk stored under refrigeration and room temperatures for six months period. In Proceedings of the 2020 ADSA Annual Meeting, West Palm Beach, FL, USA, 22-24 June 2020. Abstract. No. 81673. Virtual Presentation.

57. Huang, L. IPMP 2013-A comprehensive data analysis tool for predictive microbiology. Int. J. Food Microbiol. 2014, 171, 100-107. [CrossRef]

Publisher's Note: MDPI stays neutral with regard to jurisdictional claims in published maps and institutional affiliations. 